\title{
Efficient use of irrigation water in Irrigation District No. 041 Yaqui River, Sonora, Mexico
}

\author{
Víctor Manuel Olmedo Vázquez ${ }^{1 *}$ \\ Emilio Camacho Poyato ${ }^{2}$ \\ Juan Antonio Rodríguez Díaz ${ }^{2}$ \\ Ma. Leticia Hernández Hernández ${ }^{1}$
}

\begin{abstract}
The increasingly complex problems affecting the competitiveness and sustainability of Irrigation District No. 041 Yaqui River, located in southern Sonora, Mexico, are manifested by the lack of indicative strategies that contribute to developing needsbased planning.

The research was conducted using the logical framework, which establishes actions and projects necessary for the proper functioning of the district, using the Strengths, Weaknesses, Opportunities and Threats (SWOT) methodology.

The objective of the study was to identify the importance of the efficient use of irrigation water for competitiveness and sustainability as a determining indicator for the continuance of agricultural activity in the irrigable areas of the Irrigation District. The results corroborated the hypothesis put forward that there is a dissociation among actors (users - producers and managers). As a result, this paper proposes general organizational, comprehensive planning, and competitiveness and productivity strategies, derived from central objectives, while the specific problems identified allowed structuring projects and actions envisaged in each one of them.

The logical framework allowed determining that most of the irrigation modules can be improved by articulating the efforts of all actors at the different stages of the development of the strategic plan.
\end{abstract}

Keywords: Competitiveness, sustainability, logical framework, SWOT, strategic planning.

\section{Uso eficiente de agua de riego, en el Distrito de Riego núm. 041 Río Yaqui, Sonora, México}

\begin{abstract}
Resumen
La gradual complejidad de los problemas que afectan la competitividad y sostenibilidad del Distrito de Riego núm. 041, Río Yaqui, ubicado en el sur de Sonora, México, se manifiestan por falta de estrategias indicativas, que contribuyan a desarrollar una planeación acorde a sus necesidades.

La investigación se realizó utilizando el marco lógico, el cual establece acciones y proyectos necesarios para el buen funcionamiento del distrito, utilizando la metodología de Fortalezas, Oportunidades, Debilidades y Amenazas (FODA).

El objetivo del estudio fue, identificar la importancia del uso eficiente de agua de riego para la competitividad y sostenibilidad, como indicador determinante de permanencia de la actividad agrícola en las áreas regables del Distrito de Riego.

Los resultados permitieron corroborar la hipótesis planteada de desvinculación entre actores (usuarios - productores y directivos), estableciendo estrategias generales de organización, planeación integral, competitividad y productividad, derivadas de objetivos centrales, mientras que los problemas específicos permitieron estructurar proyectos y acciones contempladas en cada uno de ellos.

El marco lógico permitió identificar que la mayoría de los módulos de riego presentan una mejora potencial; admitiendo la articulación de esfuerzos de todos los actores en las diferentes etapas de la elaboración del plan estratégico.
\end{abstract}

Palabras clave: Competitividad, sostenibilidad, marco lógico, FODA, planeación estratégica.

'Universidad Autónoma Chapingo, Centro Regional Universitario del Noroeste, Calle Colima núm. 163 norte, Cd. Obregón, Sonora, México.

¿Universidad de Córdoba, Escuela Técnica Superior de Ingeniería Agronómica y de Montes, Departamento de Agronomía, De Campus Rabanales, Edificio Leonardo da Vinici, 14071, Córdoba, España.

*Corresponding author: olmedovazquez@gmail.com

Received: May 2, 2019

Aceptado: October 17, 2019 


\section{Introduction}

A fundamental management approach that characterizes the efficient use of irrigation water through competitiveness and sustainability in irrigable agricultural areas of Irrigation District No. 041 Yaqui River will yield a beneficial impact by developing strategic planning, which consists of multiple factors that need to be addressed. Goodstein, L., Nolan, T., and Pfeiffer, J. W. (1998) indicate that: 1) a strategy is a coherent, unifying and integrative pattern of decisions; this means that a strategy is developed in a conscious, explicit, and practical way, 2) a strategy allows establishing an organizational purpose in accordance with long-term purposes, action plans, and location of resources, 3 ) a strategy is the definition of the scope of action with which an entity seeks to be more prosperous, 4) a strategy is a response to strengths and weaknesses (internal factors) and threats and opportunities (external factors) to achieve competitive advantage, 5) a strategy becomes a logical system to differentiate the functional levels and position in the structure of managerial and operational tasks and the roles that each should have in the organization, and 6) a strategy is a way to define the contribution it makes to stakeholders; it is "their raison d'être." Considering the importance of planning, the present research projects the development of a Strategic Plan for Irrigation District No. 041 Yaqui River and its 42 irrigation modules, located in the south of the state of Sonora, Mexico.

By developing solid and consistent strategic planning, it will generate competitive and sustainable advantages in the efficient use of irrigation water and other actions related to agricultural activity, using the Logical Framework Methodology (LFM) originally developed by León J. Rosemberg and Lawrence D. Posner (1979), which considered five stages in this research: the first was to identify the actors and to provide a diagnosis of the irrigable area, the second was to identify and prioritize problems, by establishing causal relationships, and the third was to set objectives for each and every one of the problems considered; in the fourth stage, a solution model was proposed, generating concrete projects (strategies to be followed) by developing a matrix of indicators. The last stage would be the evaluation and monitoring

\section{Introducción}

Una gestión fundamental para caracterizar el uso eficiente de agua de riego a través de la competitividad y sostenibilidad en las áreas agrícolas regables del Distrito de Riego núm. 041 Río Yaqui, prosperará desarrollando una planeación estratégica, la cual consta de múltiples factores a atender. Goodstein, L., Nolan, T., y Pfeiffer, J. W. (1998) indican que, 1) la estrategia es un patrón de decisiones coherente, unificada e integradora; esto significa que la estrategia es desarrollada en forma consciente, explícita y práctica, 2) la estrategia permite establecer una finalidad organizacional acorde con los propósitos de largo plazo, planes de acción y ubicación de sus recursos, 3) la estrategia es la definición del ámbito de acción con el cual se pretende ser más prósperos, 4) la estrategia es una respuesta a las fuerzas y debilidades (internas), peligros y oportunidades (externos) para lograr una ventaja competitiva, 5) la estrategia se convierte en un sistema lógico para diferenciar los niveles funcionales y posición en la estructura de tareas directivas y operativas y los papeles que cada quien debe tener en la organización, y 6) la estrategia es una vía para definir la contribución que hace a las partes interesadas, es "su razón de ser". Considerando la importancia de la planeación, la presente investigación, proyecta la elaboración de un Plan Estratégico para el Distrito de Riego núm. 041 Río Yaqui y sus 42 módulos de riego, ubicado en el sur del estado de Sonora, México.

Al elaborar una planeación estratégica sólida y consistente, generará ventajas competitivas y sustentables en el uso eficiente del agua de riego y demás acciones vinculadas con la actividad agrícola, utilizando la Metodología de Marco Lógico (MML) elaborada originalmente por León J. Rosemberg y Lawrence D. Posner (1979), la cual, consideró cinco etapas en esta investigación: la primera fue, la de identificar a los actores y elaborar un diagnóstico del área regable, la segunda fue, identificar y priorizar problemas, estableciendo las relaciones de causalidad, la tercer etapa desarrollada fue, la de establecer objetivos para todos y cada uno de los problemas considerados; en la cuarta etapa se planteó un modelo de solución generando proyectos concretos (estrategias a seguir) elaborando una matriz de indicadores y, la última etapa sería la 
of strategic planning (in the short term), in order to identify goals and follow up on the indicators to assess whether they are being achieved (Martínez Pellegrini, S. E., Hernández D., Durazo, E., \& Barceló Aguilar J. G., 2010).

With indicative strategies, the aim is to bring about a planning discipline to build a support instrument capable of mobilizing the region's endogenous resources, since sustained productivity growth requires an economy that is continuously improving (Porter E. Michael, 1990). Collaboration and cooperation among the various actors is an essential requirement to establish the new model of inclusive development that generates competitiveness and sustainability in the Irrigation District.

The logical framework method responds to three common problems in projects (Ortegón, E., Pacheco J. F., \& Prieto A., 2005), a) project planning lacking precision, with multiple objectives that are not clearly related to project activities, b) projects that are not successfully implemented, and c) there is no clear picture of what the project would look like if it were successful.

In the mid-1960s, Development Finance Agencies promoted the creation of new methodologies to manage the implementation of projects and programs. Among the proposed solutions, the one that proved to be most attractive was the Logical Framework (or Logframe), developed by Practical Concepts Inc., a U.S. company.

In the early 1970s, the U.S. Agency for International Development (USAID) formally began to use the Logical Framework in project planning. From then on, the methodology expanded, first among the community of international development agencies, and then in the various academic and professional management fields (Aldunate, E. \& Córdoba J., 2011).

Some research projects that refer to the logical framework methodology include Modelo de planificación estratégica basado en el sistema de marco lógico. Caso de aplicación "Fundación Árbol de la Esperanza" by Bedon Martínez, M. A. (2012) (Strategic planning model based on the logical framework system, applied to the Tree of Hope Foundation, an Ecuadorian social assistance group), which is based on the linking of those involved in the diagnosis process (through tools such as the evaluación y monitoreo de la planeación estratégica (a corto plazo), con la finalidad de identificar metas y dar seguimiento a los indicadores para evaluar si éstos se están obteniendo (Martínez Pellegrini, S. E., Hernández D., Durazo, E., \& Barceló Aguilar J. G., 2010).

Con estrategias indicativas, se busca detonar una disciplina de planeación para construir un instrumento de apoyo capaz de movilizar los recursos endógenos de la región, en virtud de que el crecimiento sostenido de la productividad requiere de una economía que se perfeccione continuamente (Porter E. Michael, 1990). La colaboración y cooperación entre los diversos actores es requisito imprescindible para establecer el nuevo modelo de desarrollo incluyente y generador de competitividad y sostenibilidad en el Distrito de Riego.

El método de marco lógico da respuesta a tres problemas comunes en los proyectos (Ortegón, E., Pacheco J. F., \& Prieto A., 2005), a) planificación de proyectos carentes de precisión, con objetivos múltiples que no están claramente relacionados con las actividades del proyecto, b) proyectos que no se ejecutan exitosamente, y c) no existe una imagen clara de cómo es el proyecto si tuviese éxito.

A mediados de los años 60, las Agencias de Financiamiento al Desarrollo impulsaron la creación de nuevas metodologías para conducir la gestión de implementación de proyectos y programas. Entre las soluciones propuestas, la que resultó más atractiva fue el Marco Lógico (Logical Framework o Logframe), desarrollado en Estados Unidos por la empresa Practical Concepts Inc.

A principios de la década de los años 70, la U.S. Agency for International Development - USAID (Agencia de los Estados Unidos para el Desarrollo Internacional) comenzó formalmente a utilizar el Marco Lógico en la planeación de sus proyectos. De ahí en adelante, la metodología se expandió, primero entre la comunidad de agencias para el desarrollo internacional, y luego en los diversos ámbitos académicos y profesionales de la gestión (Aldunate, E. \& Córdoba J., 2011).

Algunas investigaciones que hacen referencia a la metodología de marco lógico son: Modelo de planificación estratégica basado en el sistema de marco lógico. Caso de aplicación "Fundación Árbol de la Esperanza" Bedon Martínez, M. A. (2012), la cual 
stakeholder matrix and the problem tree) and on strategic targeting (through the objective tree and the logical framework matrix). The application of this process has allowed its managers and collaborators to have a clear strategic direction. Conza Salas, B. A. (2003), in his research "model for the identification, formulation and evaluation of sustainable development projects applied to water supply in marginal areas: the logical framework system," determines that the use of the logical framework system facilitates understanding among the actors and those who promote the development of the project. Furthermore, it articulates everyone's efforts in the different stages of project development, which are the result of conscious and real analysis of development problems.

In the research Evaluación mediante el marco lógico del proyecto: conservación de suelos en áreas degradadas en Tlacotepec plumas, Oaxaca (Evaluation through the project's logical framework: soil conservation in degraded areas in Tlacotepec plumas, Oaxaca), author Vázquez Morales, A. L. (2013) states that the logical framework approach is important because it helps in planning a project, to better formulate one's thoughts and to express them in a clear way, and it does not attempt to do more than that. It is only a tool to improve the planning and implementation of a project or program and does not guarantee efficiency in carrying it out. The project's implementation will depend on the company responsible for the execution and the beneficiaries, as it assumes the responsibility of carrying out the activities satisfactorily with the guidelines specified; lastly, Montiel, V. M. (2016), in the research Aportaciones de la metodología de marco lógico para la integración de proyectos universitarios (Contributions of the logical framework methodology for the integration of university projects), indicates that the logical framework has tools for the diagnostic phase of the project, which can provide ease in identifying, systematizing and presenting in an orderly and understandable manner all the key information on a project proposal for its approval or rejection on a firm decision basis, as well as to identify project stakeholders from this early phase of the project and involve them in a timely manner. radica en la vinculación de los involucrados en el proceso de diagnóstico (a través de herramientas como la matriz de involucrados y el árbol de problemas) y en el direccionamiento estratégico (a través del árbol de objetivos y de la matriz de marco lógico). La aplicación de este proceso ha permitido tener claro el direccionamiento estratégico a sus directivos y a sus colaboradores. Conza Salas, B. A. (2003) en su investigación "modelo de identificación, formulación y evaluación de proyectos de desarrollo sostenible aplicado al abastecimiento de agua en zonas marginales: el sistema de marco lógico", determina que el empleo del sistema de marco lógico facilita la comprensión entre los actores y quienes promueven el desarrollo del proyecto. Además, articula los esfuerzos de todos en las diferentes etapas de elaboración de los proyectos, fruto del análisis consciente y real de la problemática del desarrollo.

En la investigación denominada "Evaluación mediante el marco lógico del proyecto: conservación de suelos en áreas degradadas en Tlacotepec plumas, Oaxaca", menciona que el enfoque del marco lógico es importante porque ayuda a la planeación de un proyecto, el formular mejor sus pensamientos y a expresarlos de forma clara, y no pretende más que eso. No es más que un instrumento para mejorar la planificación y ejecución de un proyecto o programa y no garantiza la eficiencia al efectuarla. La puesta en marcha del proyecto dependerá de la empresa responsable de la ejecución y de los beneficiarios, al asumir la responsabilidad de realizar las actividades satisfactoriamente con los lineamientos especificados en el proyecto Vázquez Morales A. L. (2013), por último, Montiel, V. M. (2016) en la investigación "Aportaciones de la metodología de marco lógico para la integración de proyectos universitarios", indica que el marco lógico tiene herramientas para la fase de diagnóstico del proyecto, que pueden aportar facilidad para identificar, sistematizar y presentar ordenada y comprensiblemente toda la información clave sobre una propuesta de proyecto para su aprobación o rechazo sobre una base firme de decisión. Así como para identificar a los involucrados del proyecto desde esta fase temprana del proyecto e involucrarlos oportunamente.

El propósito de este trabajo fue señalar estrategias que permitan analizar la eficiencia del riego a nivel 
The purpose of this work was to point out strategies that would allow for the analysis of irrigation efficiency at the module level and that could be applied in other irrigable areas in Mexico. All of the above allowed for answering questions and confirming the following hypothesis: The District and the irrigation modules present conditions of dissociation of stakeholders and resources that diminish their efficiency and competitiveness in the use of irrigation water. Therefore, the objective of the study was to identify the importance of the efficient use of irrigation water for competitiveness and sustainability, as a determining indicator of the permanence of agricultural activity in the irrigable areas of the Irrigation District.

\section{Methodology}

The logical framework methodology establishes a series of steps to arrive at the prioritization of actions and projects; given the methodology's characteristics, it should cover the following stages:

\section{Identification of actors and development of} the diagnosis: The key actors participating in the study were identified through the Irrigation District itself, by carrying out fieldwork in the forty-two irrigation modules that make up the District and its central office. These actors were: two district executives (General Director and operations manager); forty-two irrigation module executives (presidents and treasurers); fifty producers - users, fifteen zanjeros (officials in charge of water distribution) and twenty irrigators. The research was carried out in approximately eight months and a systemized information-seeking process was needed to better define the environment in which the district's agricultural production is located at the regional, national and international levels in order to define the main challenges. The research with the information obtained on the field trip is summarized in the matrix that presents the Strengths, Weaknesses, Opportunities and Threats for the project (SWOT Matrix).

\section{Identification and prioritization of problems:} By adding up the interviews carried out during the research with the different actors, módulo y que pueda ser aplicada en otras zonas regables de México. Todo lo anterior permitió responder preguntas y confirmar la siguiente hipótesis: El Distrito y los módulos de riego presentan condiciones de desvinculación de actores y recursos que disminuyen su eficiencia y competitividad en el uso de agua de riego. Por lo que, el objetivo del estudio fue, identificar la importancia del uso eficiente del agua de riego para la competitividad y sostenibilidad, como indicador determinante de permanencia de la actividad agrícola en las áreas regables del Distrito de Riego.

\section{Metodología}

La metodología del marco lógico establece una serie de pasos para llegar a la priorización de acciones y proyectos, dadas sus características, debe cubrir las siguientes etapas:

1. Identificación de actores y elaboración del diagnóstico: La identificación de los actores clave participantes en el estudio se conocieron a través del mismo Distrito de Riego, desarrollando el trabajo de campo en los cuarenta y dos módulos de riego que conforman el Distrito y la misma oficina central, los cuales fueron: Dos directivos del distrito (Director general y gerente de operación); cuarenta y dos directivos de los módulos de riego (presidentes y tesoreros), cincuenta productores usuarios, quince zanjeros (distribuidores del agua de riego) y veinte regadores. La investigación se desarrolló en aproximadamente ocho meses y fue necesario llevar a cabo un proceso sistematizado de búsqueda de información para definir mejor el entorno en el que se inscribe la producción agrícola del distrito a nivel regional, nacional e internacional para definir los principales retos. La investigación con la información obtenida en el recorrido de campo se resume en la matriz que presenta las Fortalezas, Oportunidades, Debilidades y Amenazas para el proyecto (Matriz FODA).

2. Identificación y priorización de problemas: $\mathrm{Al}$ momento de englobar las entrevistas llevadas a cabo durante la investigación con los diferentes actores, se estima haber realizado más de cien entrevistas, se identificaron los principales problemas y ventanas de oportunidad para 
it is estimated that more than one hundred interviews were conducted; the main problems and windows of opportunity for the development of the agricultural sector were identified, according to the perceptions of the participants. The problems identified as fundamental were taken as guidelines for objectives and actions.

3. Establishment of objectives: The proposal for the establishment of general or global objectives was made by the research group, setting out the purpose and scope of the long-term strategic plan. This objective is understood as the district's overall vision. Specific or immediate objectives were also formulated that reflect the changes that competitiveness and sustainability are expected to achieve in the medium and short term.

4. Solution model: In order to achieve the specific objectives set out in the strategic plan (derived from the general objective), major strategic lines were formulated for which it was necessary to establish defined results. Each strategic line had a general objective and specific objectives that guide the projects that make up the strategic line.

5. Evaluating and monitoring: Based on the results that are expected to be achieved, indicators should be established to assess whether they have been achieved or not. Monitoring should also be conducted to determine how far the activities are from or close to the objectives.

\section{Characteristics and climate in the irrigable areas of the Irrigation District}

The irrigable agricultural areas in Irrigation District No. 041 Yaqui River are located in the southeast of the state of Sonora, Mexico, covering an area of 227224 hectares of irrigated land; this region is located between $26^{\circ} 45^{\prime}$ and $27^{\circ} 40^{\prime} \mathrm{N}$ and $109^{\circ} 37^{\prime}$ and $110^{\circ} 37^{\prime} \mathrm{W}$, bordered on the north by the Yaqui River and on the south by the Mayo River, on the east by the Técali and Baroyeca mountains and on the west by the Gulf of California, comprising the municipalities of Cajeme, San Ignacio Río Muerto and Bácum, as well as part of Etchojoa, Navojoa and Benito Juárez. The district is part of the coastal plain in Northwest Mexico.

The predominant climate is within the group of very dry climates, namely very warm, warm $B W\left(h^{\prime}\right)$ hw subtypes with summer rains and a percentage el desarrollo del sector agrícola, según las percepciones de los participantes. Los problemas identificados como fundamentales se tomaron como orientadores de los objetivos y acciones.

3. Establecimiento de objetivos: La propuesta del establecimiento de objetivos generales - globales, fue realizada por el grupo de investigación, planteando el propósito y alcance del plan estratégico a largo plazo. Este objetivo se entiende como la gran visión del distrito. También se formularon objetivos específicos o inmediatos que reflejan los cambios que la competitividad y sostenibilidad espera alcanzar en el mediano y corto plazo.

4. Modelo de solución: Para alcanzar los objetivos específicos establecidos en el plan estratégico (derivados del objetivo general) se formularon grandes líneas estratégicas para las que fue necesario establecer resultados definidos. Cada línea estratégica tuvo un objetivo general y objetivos específicos que orientan los proyectos que integran la línea estratégica.

5. Evaluación y monitoreo: A partir de los resultados que se esperan alcanzar, se deberán establecer indicadores que permitan evaluar si éstos se han alcanzado o no; así como realizar una tarea de monitoreo de las actividades para conocer qué tanto se alejan o aproximan a los objetivos.

\section{Características y clima en las áreas regables del Distrito de Riego}

Las áreas agrícolas regables en el Distrito de Riego núm. 041 Río Yaqui, se localizan al sureste del estado de Sonora, México, y cuenta con una superficie de 227224 hectáreas de riego; esta región se encuentra ubicada entre los paralelos $26^{\circ} 45^{\prime}$ y $27^{\circ} 40^{\prime}$ latitud norte y entre los meridianos $109^{\circ} 37^{\prime}$ y $110^{\circ} 37^{\prime}$ longitud oeste del Meridiano de Greenwich, limitando al Norte con el Río Yaqui y al Sur con el Río Mayo, al Este limita con la serranía del Técali y Baroyeca y al Oeste con el Golfo de California, comprendiendo los municipios de Cajeme, San Ignacio Río Muerto y Bácum; así como parte de Etchojoa, Navojoa y Benito Juárez. El distrito forma parte de la planicie costera en el Noroeste de México.

El clima predominante es del grupo de climas muy secos, subtipos BW( $\left.h^{\prime}\right) h w$ muy cálido, cálido, con 
of winter precipitation between 5 and $10.2 \%$. In the northeast portion of the area there is a very warm and warm dry $\mathrm{BSo}\left(\mathrm{h}^{\prime}\right) \mathrm{hw}$ climate. The average annual temperature is $20.03^{\circ} \mathrm{C}$, average annual precipitation is $281.6 \mathrm{~mm}$-year ${ }^{-1}$ and potential evaporation is 2061.51 mm (Comisión Nacional de Agua, 2003).

Regarding agricultural production in the district, for the agricultural years 2010-2011, 2011-2012, 20122013 and 2013-2014, the importance of the activity in the region is shown in Table 1.

The region's main problem is drought, which is a very complex phenomenon caused by meteorological anomalies, which reduce precipitation levels below average and which, when it lasts for an agricultural year or for longer periods, makes the precipitation insufficient to respond to the demands of the different water users and the environment. This precipitation deficit can manifest itself in very short periods; the slow, stealthy evolution of droughts means that, at times, their effects can take months and even years to manifest themselves, adversely affecting water runoff in the river, storage levels in the dam system and even groundwater levels.

Determining when a drought begins and ends is not easy, and most of Mexico's irrigation districts do not currently have the criteria for deciding when a drought has started and when it has ended. Another factor that further complicates the question of whether there is a drought or not is the absence of a precise and universally accepted definition of it. The definition of drought should respond to the characteristics of the affected region, since droughts lluvias de verano y un porcentaje de precipitación invernal entre 5 y $10.2 \%$. En la porción noreste de la zona se presenta un clima BSo(h')hw seco muy cálido y cálido. La temperatura media anual es de $20.03^{\circ} \mathrm{C}$, precipitación media anual de $281.6 \mathrm{~mm} \cdot \mathrm{año}^{-1}$ y una evaporación potencial de 2061.51 mm (Comisión Nacional de Agua, 2003).

En lo que respecta a la producción agrícola en el distrito, para los años agrícolas 2010-2011, 2011-2012, 2012-2013 y 2013-2014; se muestra la importancia de la actividad en la región (Cuadro 1).

El principal problema de la región es enfrentarse a una sequía, la cual es un fenómeno muy complejo que se origina por anomalías meteorológicas, las cuales reducen los niveles de precipitación por debajo de la media $y$, que, cuando se prolonga durante un año agrícola o durante periodos más largos, hace que las precipitaciones sean insuficientes para responder a las demandas de los diferentes usuarios del agua y del medio ambiente. Este déficit de precipitación puede manifestarse en periodos muy cortos, la evolución sigilosa y lenta de la sequía hace que, en ocasiones, sus efectos puedan tardar meses e incluso años en manifestarse afectando de manera adversa el escurrimiento del agua en el río, los niveles de almacenamiento en el sistema de presas e incluso los niveles del agua subterránea.

No es sencillo determinar cuándo empieza y cuándo termina una sequía, y en la actualidad, la mayor parte de los distritos de riego de México no cuentan con los criterios para decidir cuándo ha empezado y cuándo ha terminado una sequía. Otro

Table 1. Annual agricultural production in Irrigation District No. 041 Yaqui River.

Cuadro 1. Producción agrícola anual en el Distrito de Riego núm. 041, Río Yaqui.

\begin{tabular}{ccccc}
\hline \multirow{2}{*}{$\begin{array}{c}\text { Agricultural year / } \\
\text { Año Agrícola }\end{array}$} & \multicolumn{2}{c}{$\begin{array}{c}\text { Area / } \\
\text { Superficie }\end{array}$} & $\begin{array}{c}\text { Production (t) / } \\
\text { Producción (t) }\end{array}$ & $\begin{array}{c}\text { Production value (\$) / } \\
\text { Valor de la producción (\$) }\end{array}$ \\
\cline { 2 - 3 } & $\begin{array}{c}\text { Sown (ha) / } \\
\text { Sembrada (ha) }\end{array}$ & $\begin{array}{c}\text { Harvested (ha) / } \\
\text { Cosechada (ha) }\end{array}$ & \\
\hline $2010-2011$ & 217.501 & 217.201 & 1.719 .427 & 4.714 .358 .286 \\
$2011-2012$ & 218.029 & $\mathrm{t} 217.065$ & 1.604 .022 & 5.757 .256 .951 \\
$2012-2013$ & 217.502 & 216.519 & 1.779 .748 & 7.149 .649 .646 \\
$2013-2014$ & 220.500 & 217.584 & 1.924 .376 & 9.008 .696 .540 \\
Average / Promedio & 218.383 & 217.092 & 1.756 .893 & 6.657 .490 .355 \\
\hline
\end{tabular}


are regional and each region has specific and different climatic and infrastructure characteristics.

Given the hydro-agricultural infrastructure conditions of the Yaqui Basin (storage dams and deep wells), drought is not only considered to be a physical phenomenon that can be defined solely by the climate, as most people assume, since, in this basin, drought can also be caused by an increase in the demand for available water during periods of average runoff or even during dry periods. In this way, drought in the Yaqui Basin can be seen as a balance between the available water and the water demanded by the different users.

Considering that competitiveness and sustainability imply improving the living conditions of the district's producers, they establish permanent goals in the different agricultural activities they develop to achieve greater productivity in their activity and to be more competitive with respect to the conditions prevailing at the national and international level. In this regard, it can be seen that the district's development inevitably implies the existence of a process of economic development, which involves describing a model that helps to improve the conditions of agricultural activity.

In any innovation plan for the regional-local systems as developed by the district, an endogenous development process is determined that leads to a gain in competitiveness. Porter E. Michael (1990) indicates that competitiveness has become one of the cardinal concerns of government and businesses in each and every nation. He states that the only significant concept of competitiveness at the national level is national productivity. A rising standard of living depends on the ability of a country's businesses to achieve high levels of productivity and to increase it over time. Sustained productivity growth requires an economy to continually improve.

In relation to the above, Porter's diamond was considered, from the perspective of the water resource, through the Mexican government, where this government must act as a catalyst and competitor, having to support in greater measure the Irrigation District (which is a limited liability company, created by producers to serve themselves, committed to contributing to the sustainable factor que complica más la confusión en torno a la realidad o no de una sequía, es la ausencia de una definición precisa y universalmente aceptada de la misma. La definición de sequía debería responder a las características propias de la región afectada, ya que las sequías son regionales y cada región presenta características climáticas y de infraestructura específica y diferente.

Dadas las condiciones de infraestructura hidroagrícola con que cuenta la Cuenca del Yaqui (presas de almacenamiento y pozos profundos), se considera que la sequía no es únicamente un fenómeno físico que puede ser definida únicamente por el clima, como la mayor parte de las personas asume, por lo que, en esta cuenca la sequía también puede ser causada por un incremento en la demanda del agua disponible durante periodos de escurrimientos promedio o incluso durante periodos secos. De esta manera, la sequía en la Cuenca del Yaqui puede verse como un balance entre el agua disponible y el agua demandada por los diferentes usuarios.

Considerando que la competitividad y sostenibilidad implica mejorar las condiciones de vida de los productores del distrito, éstos establecen metas permanentes en las distintas actividades agrícolas que desarrollan para lograr una mayor productividad en su actividad y ser más competitivos con respecto a las condiciones que imperan a nivel nacional e internacional. A este respecto, se observa que el desarrollo del distrito implica inevitablemente la existencia de un proceso de desarrollo económico, lo cual involucra describir un modelo que coadyuve a mejorar las condiciones de la actividad agrícola.

En todo planteamiento de innovación de los sistemas regionales-locales como lo desarrolla el distrito, se determina un proceso de desarrollo endógeno que conduce hacia la ganancia de competitividad. Porter E. Michael (1990), indica que, la competitividad ha pasado a ser una de las preocupaciones cardinales del gobierno y las empresas de todas y cada una de las naciones. Menciona que el único concepto significativo de la competitividad a nivel nacional es la productividad nacional. Un creciente nivel de vida depende de la capacidad de las empresas de un país para alcanzar altos niveles de productividad y para aumentarla con 
development of the community, concerned with providing solutions to meet current water needs, but also committed to taking care of the needs of future generations), and, at the same time, the irrigation modules in order to make them more competitive, as shown in Figure 1. In addition, all those involved are proactively influenced by the same government, where: the Customers are people or companies el transcurso del tiempo. El crecimiento sostenido de la productividad requiere que una economía se perfeccione continuamente.

En relación con lo anterior, se consideró el diamante de Porter, desde la perspectiva del recurso agua, a través del gobierno mexicano, donde este gobierno debe actuar como catalizador y competidor, teniendo que apoyar en mayor medida al Distrito de

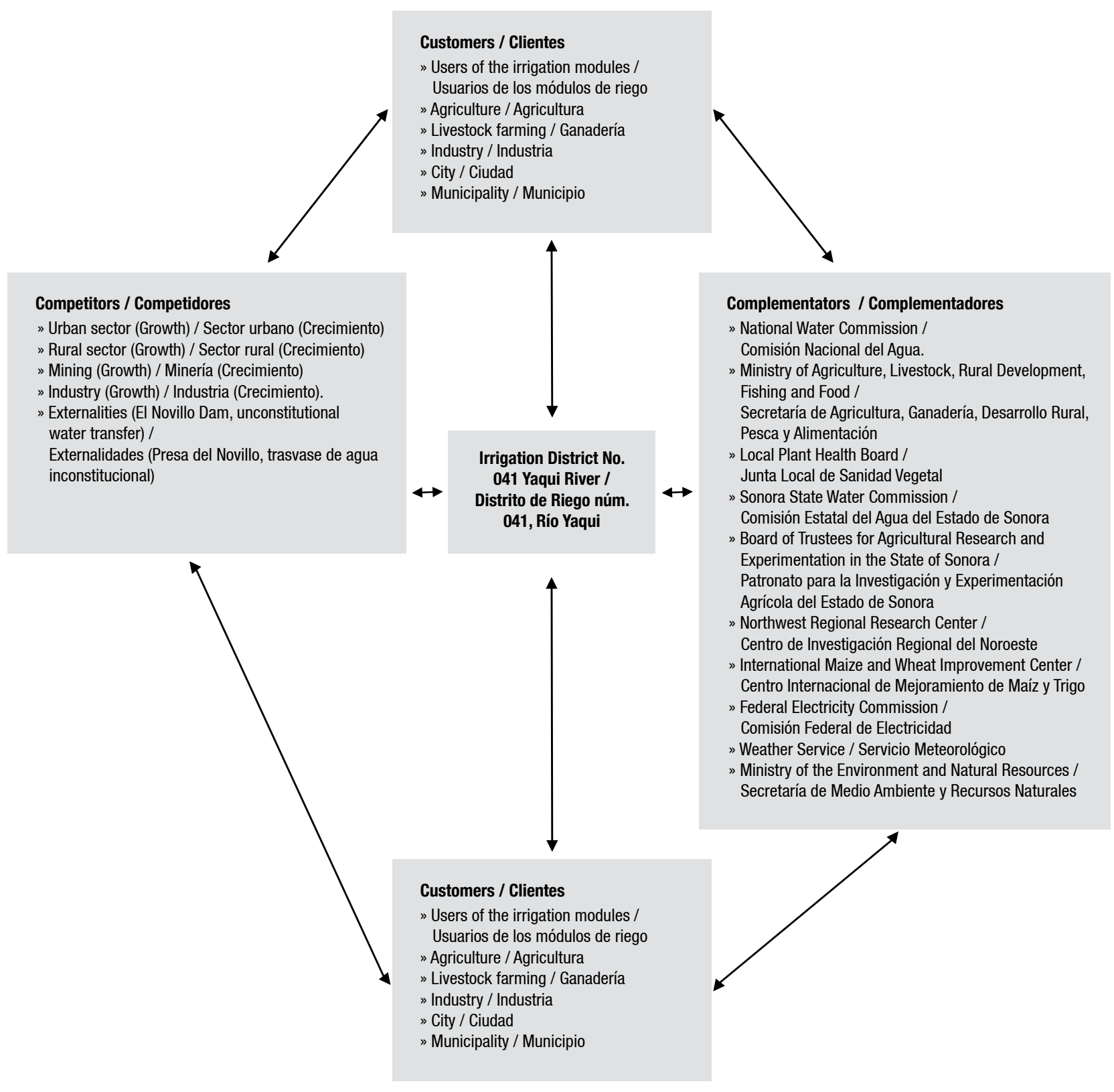

Figure 1. Porter's Diamond adapted to Irrigation District No. 041 Yaqui River.

Figura 1. Diamante de Porter adaptado al Distrito de Riego núm. 041, Río Yaqui. 
receiving the good, service or product (in this case the water resource) in exchange for money; the Complementators are considered as coopetition, expanding the market with reciprocal benefit; the Suppliers provide what is necessary for a purpose, and the Competitors are considered as competition where economic agents are free to offer goods and services in the market.

Once the actors' intervention in competitiveness has been achieved, they must specialize and improve dynamically, in order to achieve sustainability in agricultural production, with the premise of developing it in a socially just, economically profitable and ecologically friendly manner. As a society, there is a commitment to deliver the district's agricultural area to future generations in a sustainable manner over time.

\section{Results and discussion}

\section{Situation of agricultural activity and alternative solutions}

In recent years, the state of Sonora has experienced atypical weather conditions, influenced by the presence of extraordinary meteorological phenomena, causing problems in the collection of water in the different storage systems.

Considering that part of the irrigation water is lost in the district due to the lack of lined distribution canals, both in the main canals that are $292 \mathrm{~km}$ long and of which only $91 \mathrm{~km}$ (31\%) are lined, as well as the secondary canals that are $3204 \mathrm{~km}$ long and of which only $776.8 \mathrm{~km}$ (24.2\%) are lined, in addition to including the form of irrigation application in each of the modules. Therefore, irrigation water delivery (under a program) must be as efficient as possible in the side canal intakes or direct intakes of the irrigation modules to the representatives of the Civil Associations, which distribute and provide directly or through the zanjeros (officials in charge of water distribution) the irrigation service to the users. In addition, problems with the lining and piping of the irrigation outlets must be considered, as well as the levelling of agricultural land and the implementation of plot drainage to clean up soils with salinity problems.

In Mexico's irrigation districts, canal conveyance efficiency has been estimated at $65 \%$ and at the
Riego (el cual es una Sociedad de responsabilidad limitada, creada por productores para el servicio de los mismos, comprometidos a contribuir con el desarrollo sustentable de la comunidad, preocupados por aportar soluciones para solventar las necesidades de agua actuales, pero además, comprometidos también a cuidar las necesidades de las generaciones futuras), y a la vez, a los módulos de riego con el propósito de hacerlos más competitivos, como se observa en la Figura 1, además de que todos los involucrados presentan influencia de manera proactiva por el mismo gobierno, donde: Los Clientes, son personas o empresas receptoras del bien, servicio o producto (en este caso el recurso agua) a cambio de dinero, los Complementadores, son considerados como coopetencia, ampliando el mercado con beneficio recíproco, los Proveedores suministran lo necesario para un fin, y los Competidores son considerados como competencia donde los agentes económicos tienen la libertad de ofrecer bienes y servicios en el mercado.

Una vez lograda la intervención de los actores en la competitividad, deberán especializarse y mejorar dinámicamente, con el propósito de lograr una sustentabilidad en la producción agrícola, con la premisa de desarrollarla socialmente justa, económicamente rentable y ecológicamente amigable con el medio ambiente. Como sociedad se tiene el compromiso de entregar el área agrícola del distrito a futuras generaciones de manera sostenible en el tiempo.

\section{Resultados y discusión}

\section{Situación de la actividad agrícola y alternativas de solución}

En los últimos años, en el estado de Sonora, se han presentado condiciones climatológicas atípicas al comportamiento generalmente mostrado, influenciadas por la presencia de fenómenos meteorológicos extraordinarios, provocando problemas en la captación de agua en los diferentes sistemas de almacenamiento.

Al considerar que parte del agua de riego se pierde en el distrito, a través de la distribución por falta de canales revestidos tanto en los canales principales que comprenden $292 \mathrm{~km}$ de longitud y de los cuales se encuentran revestidos únicamente 91 km (31\%), 
parcel level at $52.5 \%$. To obtain the overall efficiency, conveyance efficiency is multiplied by plot-level efficiency, which results in $34.1 \%$; that is, of every 1 000 liters of water for irrigation, the crop uses only 341 liters.

In Irrigation District 041, canal conveyance efficiency has been estimated at $65 \%$, resulting in a plot-level efficiency of $70 \%$ and inter-plot (plot canals) efficiency of $85 \%$, which translates into $59.5 \%$ plot efficiency. To obtain the overall efficiency, conveyance efficiency multiplied by plot-level efficiency of the plot is considered, which results in $38.68 \%$; that is, of every 1,000 liters of water for irrigation, the crop uses only 386.8 liters (Olmedo, Camacho, Rodríguez, Minjares, \& Hernández, 2017).

The current critical situation regarding the high incidence of rent of agricultural land shows that more than $85 \%$ is rented between the user (landowner) and the producer (renter) in the region, which has not been properly measured by both governments and users, since these effects are beginning to appear and there are not enough alternatives to reduce them, causing social and economic problems of a structural nature for the region, since the plots are being eroded or simply the agricultural activity is ceasing to be profitable for those who produce. In addition to this problem, there is also the increase in pest population levels, the spread of diseases, high production costs, late government support for the production and marketing of basic grains, and health standards for exports, among others. The findings were as follows:

- There is a clear need to adapt agricultural production in the irrigation modules to the conditions of their resources and the current trade opening framework.

- The irrigation modules have seen a marked economic dependence, due to monoculture (wheat in up to $75 \%$ of the planted area).

- In recent years, some problems have become even more acute, such as: reduced prices, high production costs and a lack of care in water management by the irrigation modules and the district itself.

- In the face of a higher incidence of pests and diseases, ecological deterioration is increasing. así como de los canales secundarios que cuentan con $3204 \mathrm{~km}$ de longitud y de los cuales únicamente 776.8 km (24.2 \%) están revestidos, además de incluir la forma de aplicación del riego en cada uno de los módulos. Por ello, es necesario que el agua de riego cuando se entrega (bajo programa) en las bocatomas de canales laterales o tomas directas de los módulos de riego a los representantes de las Asociaciones Civiles, mismos que distribuyen y proporcionan directa o a través de los "zanjeros" el servicio de riego a los usuarios, sea lo más eficiente posible. Además de considerar problemas de revestimiento y entubamiento de las regaderas, así como nivelación de terrenos agrícolas e implementación de drenaje parcelario para sanear suelos con problemas de salinidad.

En los distritos de riego en México, la eficiencia de conducción en canales se ha estimado en el orden del $65 \%$ y a nivel parcelario en un $52.5 \%$. Para obtener la eficacia global, se considera la eficiencia de conducción multiplicada por la eficiencia a nivel parcelario, la cual da como resultado un $34.1 \%$; es decir, de cada 1000 litros de agua para riego, el cultivo aprovecha únicamente 341 litros.

En el Distrito de Riego 041, la eficiencia de conducción en canales se ha estimado en el orden del $65 \%$, dando como resultado una eficiencia a nivel parcelario del $70 \%$ e interparcelario (canales de la parcela) del $85 \%$, lo cual se traduce en un $59.5 \%$ de eficiencia parcelaria. Para obtener la eficiencia global, se considera la eficiencia de conducción multiplicada por la eficiencia de la parcela, la cual da como resultado un $38.68 \%$; es decir, de cada 1000 litros de agua para riego, el cultivo aprovecha únicamente 386.8 litros (Olmedo, Camacho, Rodríguez, Minjares, \& Hernández, 2017).

La crítica situación actual con respecto a la alta incidencia de renta de la superficie agrícola, manifiesta que más del $85 \%$, se encuentran rentadas entre usuario (dueño de la tierra) y el productor (arrendatario) en la región, lo cual no ha sido debidamente dimensionada tanto por los gobiernos y por los usuarios, ya que estos efectos se empiezan a presentar y no se cuentan con alternativas suficientes para aminorarlos, causando problemas de tipo social y económico de carácter estructural para la región, ya que las parcelas están siendo desgastadas o simplemente la actividad agrícola está dejando de ser rentable para quienes 
- In the event of a phytosanitary emergency, such as that which occurred with wheat leaf rust in previous cycles, the region is very susceptible to losses due to the low diversification of crops and activities, as well as the insufficient availability of equipment and products for preventative purposes.

- The problems of harvesting, transporting, storing and marketing grains are aggravated in a very short harvest period.

- Opportunities provided by productive conversion to export crops have been squandered, with the regional economy remaining dependent on a single crop. A conversion agriculture has the following advantages: saving of natural resources and less pollution, diversification of production and activities, improvements in productivity and competitiveness, consolidation of a new productive culture, use of state-of-the-art technology and integration of production chains that can reactivate the district's economic and social model and make a greater contribution to the integrated development of the modules and the irrigation district.

Table 2 sets out the main findings of the analysis of the agricultural sector environment in the Irrigation District, both internally and externally, to determine its Strengths, Weaknesses, Opportunities and Threats (SWOT).

\section{Determination of problems and objectives}

Based on the diagnosis in the study area, central problems and general objectives were identified that are listed in Table 3.

\section{Specific problems:}

The direct work with those involved (irrigation modules) in the agricultural activity allowed detecting the following specific problems that in some cases are causes and in others result from the central problems (Table 4).

\section{Strategy formulation}

The general strategies were derived from the two central objectives, while the specific problems allowed structuring the projects and actions envisaged in each of them. producen, además de sumar también a este problema el aumento en los niveles de población de plagas, la radicación de enfermedades, los altos costos de producción, los apoyos gubernamentales tardíos a la producción y comercialización de granos básicos, las normas sanitarias a las exportaciones, entre otros. Encontrando el siguiente entorno en la investigación:

- Existe evidente necesidad de adecuar la producción agrícola en los módulos de riego a las condiciones de sus recursos y al marco de apertura comercial actual.

- Los módulos de riego han visto muy marcada la dependencia económica, debido al monocultivo (trigo hasta el $75 \%$ de la superficie sembrada).

- En los últimos años se han agudizado aún más problemas como: precios reducidos, altos costos de producción y falta de cuidado en el manejo del recurso agua por parte de los módulos de riego y del mismo distrito.

- Ante mayor incidencia de plagas y enfermedades, aumenta el deterioro ecológico.

- En caso de presentarse una emergencia fitosanitaria, como la ocurrida con la roya de la hoja del trigo en ciclos anteriores, la región es muy susceptible a sufrir pérdidas por la escasa diversificación de cultivos y de actividades, así como la disponibilidad insuficiente de equipos y productos para su prevención.

- Los problemas de recolección, transporte, acopio y comercialización de granos se agudizan en un periodo muy corto de la cosecha.

- Se han desaprovechado oportunidades que brinda la reconversión productiva orientada a cultivos de exportación, dependiendo de la economía regional de un solo cultivo. Una agricultura de reconversión presenta las ventajas siguientes: ahorro de recursos naturales y menor contaminación, diversificación de la producción y las actividades, mejoras en la productividad y competitividad, consolidación de una nueva cultura productiva, utilización de tecnología de punta e integración de cadenas productivas que pueden reactivar el modelo de desarrollo económico y social del distrito y mayor contribución al desarrollo integral de los módulos y el distrito de riego. 
Table 2. Strengths, Weaknesses, Opportunities and Threats (SWOT). Cuadro 2. Fortalezas, Oportunidades, Debilidades y Amenazas (FODA).

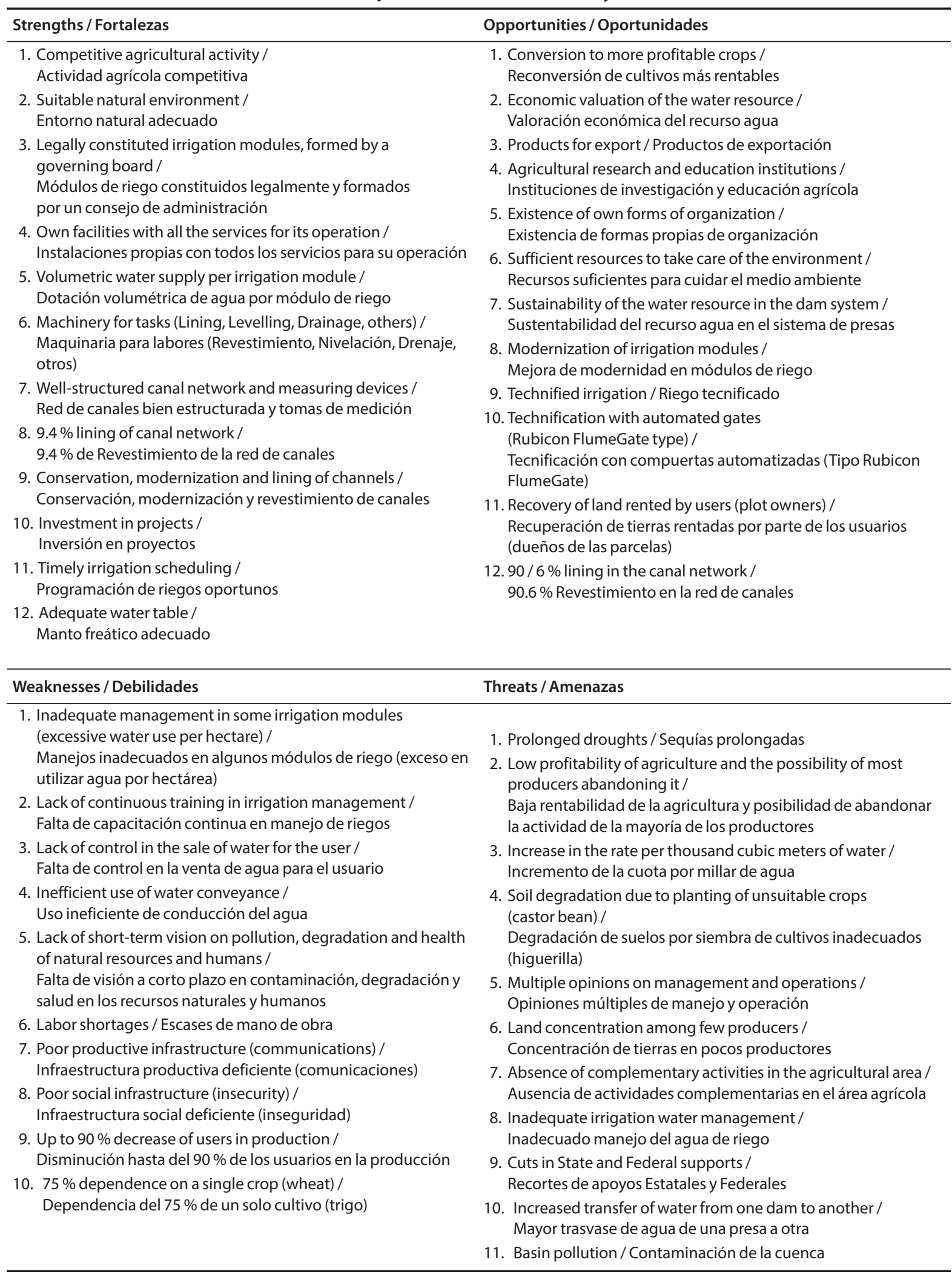


Table 3. Central problems and general objectives.

Cuadro 3. Problemas centrales y objetivos generales.

\begin{tabular}{|c|c|}
\hline Central problems / Problemas centrales & General objectives / Objetivos generales \\
\hline $\begin{array}{l}\text { Little conversion of agricultural activity and lack of } \\
\text { profitability in the activity / }\end{array}$ & $\begin{array}{l}\text { Development of competitive and sustainable agricultural } \\
\text { activity / }\end{array}$ \\
\hline $\begin{array}{l}\text { Escasa reconversión de la actividad agrícola y falta de } \\
\text { rentabilidad en la actividad }\end{array}$ & $\begin{array}{l}\text { Desarrollo de la actividad agrícola competitiva y } \\
\text { sostenible }\end{array}$ \\
\hline $\begin{array}{l}\text { Little articulation between irrigation modules to generate } \\
\text { a common and operational project / } \\
\text { Poca articulación entre módulos de riego para generar un } \\
\text { proyecto común y operativo }\end{array}$ & $\begin{array}{l}\text { Establishment of a comprehensive planning framework } \\
\text { that allows the implementation and monitoring of a long- } \\
\text { term development project for the Irrigation District / } \\
\text { Establecimiento de un marco de planeación integral que } \\
\text { permita la implementación y seguimiento de un proyecto } \\
\text { de desarrollo a largo plazo para el Distrito de Riego }\end{array}$ \\
\hline
\end{tabular}

Table 4. Specific problems

Cuadro 4. Problemas específicos

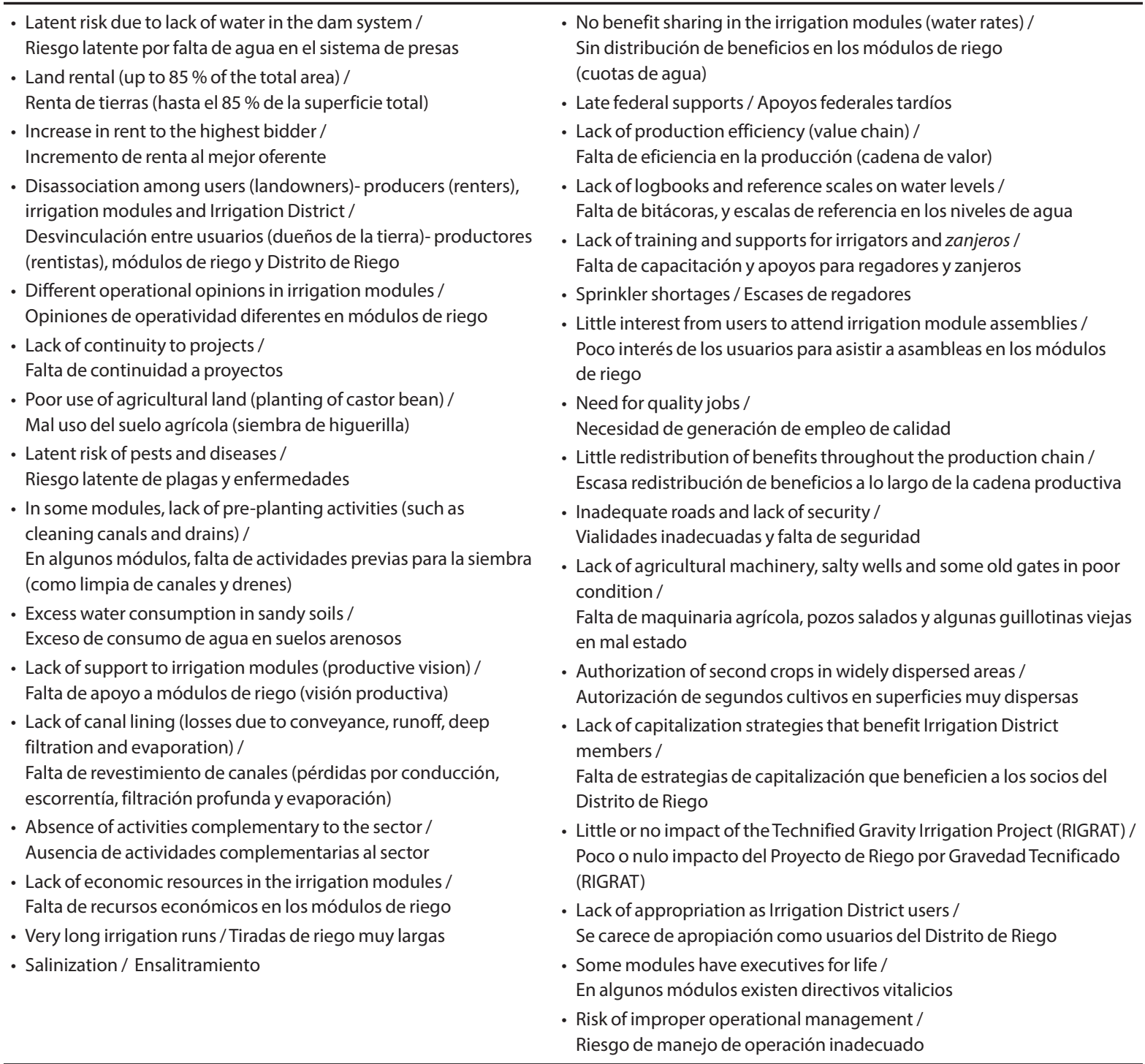




\section{STRATEGY 1: ORGANIZATION}

General Objective: In the short term, give immediate follow-up to the actions proposed by each of the irrigation modules in order to create spaces of unity and equality. In the medium term, establish permanent training mechanisms and organizational capacity that allow sustained improvement in the competitiveness of the productive activities undertaken in the irrigation modules. In the long term, achieve a development model capable of incorporating all the users of the irrigation modules so that the agricultural activity really works as it was initially proposed and not concentrate the activity in a few producers.

\section{Projects:}

\section{Strengthening of the Governing Council.}

Objective: Review the existing regulatory framework that affects agricultural activity, proposing initiatives to improve the regulatory context and that intervene in the monitoring and evaluation of agricultural sector projects (Table 5).

\section{STRATEGY 2: INTEGRATED PLANNING.}

General Objective: In the short term, ensure the completion of the projects already underway and the start of other complementary ones. In the medium and long term, follow up on the regulations
En el Cuadro 2, se exponen los principales hallazgos del estudio de análisis del entorno del sector agrícola en el Distrito de Riego, en los ámbitos interno como en el externo, para conocer las Fortalezas, Oportunidades, Debilidades y Amenazas (FODA) del mismo.

\section{Establecimiento de problemas y objetivos}

A partir del diagnóstico en el área de estudio, se identificaron problemas centrales y objetivos generales que se proyectan en el Cuadro 3.

\section{Problemas específicos:}

El trabajo directo con los involucrados (módulos riego) en la actividad agrícola, permitió detectar los siguientes problemas específicos que en algunos casos son causas y en otros, resultado de los problemas centrales.

\section{Formulación de estrategias}

Las estrategias generales se derivaron de los dos objetivos centrales, mientras que los problemas específicos permitieron estructurar los proyectos y las acciones contempladas en cada uno de ellos.

\section{ESTRATEGIA 1: ORGANIZACIÓN}

Objetivo General: A corto plazo, dar seguimiento inmediato a las acciones que planteé cada uno

Table 5. Actions and results to be followed to strengthen the Governing Council. Cuadro 5. Acciones y resultados a seguir para el fortalecimiento del Consejo de Administración.

\begin{tabular}{ll}
\hline Actions / Acciones & Results / Resultados \\
\hline $\begin{array}{l}\text { Strengthening the structure of the Governing Board, } \\
\text { its functions and sources of funding for the irrigation } \\
\text { modules / }\end{array}$ & $\begin{array}{l}\text { Have a tracking plan / } \\
\text { Contar con un documento (plan de seguimiento) }\end{array}$ \\
Fortalecimiento de la estructura del Consejo de & \\
Administración, sus funciones y fuentes de & \\
financiamiento para los módulos de riego & \\
\hline
\end{tabular}

Development of a long-term strategic plan / Elaboración de un plan estratégico a largo plazo
Have a guiding, consensual document on the development of the irrigation modules and the identification of those responsible for promoting the proposals /

Contar con un documento rector del desarrollo de los módulos de riego consensado e identificación de responsables para impulsar las propuestas 
that contribute to the competitive and sustainable development of irrigation modules in balance with their productive nature and socioeconomic needs.

\section{Projects:}

1. Ecological and territorial zoning (agricultural nature of the region).

Objective: Establish territorial zoning that ensures respect for the region's productive activities, as well as the most appropriate use of land to ensure the competitiveness and sustainability of the area's development. These management instruments will provide the framework for integrating environmental conservation with the development of productive activities in the area (Table 6).

\section{Implementation and monitoring of the strategic plan.}

Objective: Have a strategic plan (Table 7) that integrates and orders the different actions undertaken in the Irrigation District to achieve:

The establishment of a comprehensive planning framework that allows the implementation and monitoring of a long-term development project.

Development of agricultural activity and connected or related activities.

\section{Review of agreements and long-term sustainable water use plan.}

Objective: In the short term, regularize the existing situation regarding previous agreements on water use. In a medium- and long-term horizon, establish, based on a hydrological diagnosis of the area, a sustainable water use plan to ensure the Irrigation District's supply of the resource in the future (Table 8). de los módulos de riego con la finalidad de crear espacios de unidad e igualdad. A mediano plazo, establecer mecanismos de capacitación permanente y capacidad organizativa que permitan una mejora sostenida de la competitividad de las actividades productivas emprendidas en los módulos de riego. A largo plazo, lograr detonar un modelo de desarrollo capaz de incorporar a todos los usuarios de los módulos de riego para que realmente funcione la actividad agrícola como fue planteada inicialmente y no concentrar la actividad en pocos productores.

\section{Proyectos:}

1. Fortalecimiento del Consejo de Administración. Objetivo: Revisar el marco normativo existente que afecte la actividad agrícola, proponiendo iniciativas para mejorar el contexto normativo y que intervenga en el seguimiento y evaluación de los proyectos del sector agrícola (Cuadro 5).

\section{ESTRATEGIA 2: PLANEACIÓN INTEGRAL.}

Objetivo General: A corto plazo, asegurar la conclusión de los proyectos ya emprendidos y el inicio de otros complementarios. A mediano y largo plazo, dar seguimiento a las normatividades que coadyuven al desarrollo competitivo y sustentable de los módulos de riego en equilibrio con su vocación productiva y necesidades socioeconómicas.

\section{Proyectos:}

1. Ordenamiento ecológico y territorial (vocación agrícola de la región).

Objetivo: Establecer los ordenamientos territoriales que aseguren el respeto a la vocación productiva de

Table 6. Actions and results to be followed in ecological and territorial zoning. Cuadro 6. Acciones y resultados a seguir en el ordenamiento ecológico y territorial.

\begin{tabular}{ll}
\hline Actions / Acciones & Results / Resultados \\
\hline $\begin{array}{l}\text { Development of the ecological zoning of the region / } \\
\text { Elaboración del ordenamiento ecológico de la región }\end{array}$ & $\begin{array}{l}\text { Establishment of optimal land uses and census of natural } \\
\text { resources / } \\
\text { Establecimiento de usos de suelo óptimos y censo de } \\
\text { recursos naturales }\end{array}$ \\
\hline $\begin{array}{l}\text { Preparation of specific zoning plans for the region's } \\
\text { urban and rural areas / }\end{array}$ & $\begin{array}{l}\text { Have the urban and rural zoning of a development plan for } \\
\text { infrastructures and services in these areas / } \\
\text { Claboración de planes de ordenamiento específicos } \\
\text { para las zonas urbanas y rurales de la región }\end{array}$ \\
\hline
\end{tabular}


Table 7. Actions and results to be followed for the strategic plan.

Cuadro 7. Acciones y resultados a seguir para el plan estratégico.

\begin{tabular}{|c|c|}
\hline Actions / Acciones & Results / Resultados \\
\hline $\begin{array}{l}\text { Consensual identification and discussion of priority } \\
\text { projects in the Irrigation District's strategic plan / } \\
\text { Identificación y discusión consensada de proyectos } \\
\text { prioritarios del plan estratégico del Distrito de Riego }\end{array}$ & $\begin{array}{l}\text { Cooperation agreements and obtaining of funding for } \\
\text { the development of projects / } \\
\text { Acuerdos de cooperación y consecución de } \\
\text { financiamiento para el desarrollo de los proyectos }\end{array}$ \\
\hline $\begin{array}{l}\text { Monitoring of cooperation projects and agreements / } \\
\text { Seguimiento de los proyectos y acuerdos de cooperación }\end{array}$ & $\begin{array}{l}\text { Achievement of the objectives and goals of the projects } \\
\text { carried out, and evaluation of the projects / } \\
\text { Logro de los objetivos y metas de los proyectos } \\
\text { realizados, evaluación de los proyectos }\end{array}$ \\
\hline $\begin{array}{l}\text { Review of the strategic plan: review of projects carried } \\
\text { out, their results and adjustment of the plan based } \\
\text { on what has been achieved, what is pending and the } \\
\text { problems detected / } \\
\text { Revisión del plan estratégico: revisión de proyectos } \\
\text { realizados, sus resultados y ajuste del plan de acuerdo } \\
\text { con lo logrado, lo pendiente y los problemas detectados }\end{array}$ & $\begin{array}{l}\text { Updating of the plan, progress assessment and new } \\
\text { proposals every two years / } \\
\text { Actualización del plan, evaluación de avances y nuevas } \\
\text { propuestas cada dos años }\end{array}$ \\
\hline
\end{tabular}

Table 8. Actions and results to be followed in the use of water.

Cuadro 8. Acciones y resultados a seguir en el uso del agua.

\begin{tabular}{|c|c|}
\hline Actions / Acciones & Results / Resultados \\
\hline $\begin{array}{l}\text { Updating and conducting the hydrological study of the } \\
\text { region and preparation of a plan for the sustainable use of } \\
\text { the resource / } \\
\text { Actualización y realización del estudio hidrológico de la } \\
\text { región y elaboración de un plan de uso sustentable del } \\
\text { recurso }\end{array}$ & $\begin{array}{l}\text { Hydrological study of the area and a proposal for } \\
\text { sustainable use of the resource / } \\
\text { Estudio hidrológico del área y propuesta de uso } \\
\text { sustentable del recurso }\end{array}$ \\
\hline $\begin{array}{l}\text { Renegotiation of current water supply agreements / } \\
\text { Renegociación de los actuales acuerdos de abastecimiento } \\
\text { de agua }\end{array}$ & $\begin{array}{l}\text { Updating information on water use and initiatives to } \\
\text { regularize irregular uses (Novillo Dam) / } \\
\text { Actualización de la información sobre uso del agua e } \\
\text { iniciativas para la regularización de los usos irregulares } \\
\text { (Presa el Novillo) }\end{array}$ \\
\hline $\begin{array}{l}\text { Implementation of the actions covered by the sustainable } \\
\text { water use plan / } \\
\text { Implementación de las acciones contempladas en el plan } \\
\text { de uso sustentable del agua }\end{array}$ & $\begin{array}{l}\text { Incorporation of sustainable water management in all } \\
\text { regulations applicable to the area. } \\
\text { Control measures to respect the regulations / } \\
\text { Incorporación del manejo sustentable del agua a todas las } \\
\text { normatividades aplicables a la zona. } \\
\text { Medidas de control de respeto a la normatividad. }\end{array}$ \\
\hline
\end{tabular}

\section{STRATEGY 3: COMPETITIVENESS AND PRODUCTION}

General objective: Increase competitiveness through actions on aspects related to all stages of production. This strategy seeks to diversify activities and attempts to articulate some production chains in the irrigation modules. This strategy is closely related to the results obtained from the study on the sector's value chain that is currently underway. la región, así como el uso más adecuado del suelo para asegurar la competitividad y sustentabilidad del desarrollo de la zona. Estos instrumentos de ordenamiento proporcionarán el marco de integración de la conservación del medio con el desarrollo de actividades productivas en el área (Cuadro 6).

\section{Implementación y seguimiento del plan estratégico. Objetivo: Contar con un plan estratégico (Cuadro 7)}




\section{PROJECTS:}

\section{Growth of agriculture.}

Objective: Ensure that the technology used in each of the stages related to agricultural production can achieve efficiency and quality standards (Table 9).

\section{Increase in production.}

Objective: Increase the importance of agriculture in the region's economy in terms of value added and employment (Table 10).

\section{Conclusions}

Through the analysis conducted and based on the logical framework as a central methodology, focused on the district and the irrigation modules, it was determined that the hypothesis set forth in the research is fulfilled, since there is a dissociation among actors (users-producers and managers) that que integre y ordene las diferentes acciones emprendidas en el Distrito de Riego para lograr:

El establecimiento de un marco de planeación integral que permita la implementación y seguimiento de un proyecto de desarrollo a largo plazo.

Desarrollo de la actividad agrícola y actividades conexas o relacionadas.

\section{Revisión de los acuerdos y plan de uso sustentable del agua a largo plazo.}

Objetivo: En el corto plazo, regularizar la situación existente respecto a acuerdos previos sobre el uso del agua. En un horizonte de mediano y largo plazo establecer, a partir de un diagnóstico hidrológico de la zona, un plan de uso del agua sustentable que permita garantizar el abasto del recurso en el Distrito de Riego en el futuro (Cuadro 8).

Table 9. Actions and results to be followed for the growth of agriculture.

Cuadro 9. Acciones y resultados a seguir para el crecimiento de la agricultura.

\begin{tabular}{ll}
\hline Actions / Acciones & Results / Resultados \\
\hline $\begin{array}{l}\text { Conduct an agricultural value chain study / } \\
\text { Realizar un estudio de cadena de valor de la agricultura }\end{array}$ & $\begin{array}{l}\text { Estimation of opportunities to improve productivity / } \\
\text { Estimación de oportunidades para mejorar la } \\
\text { productividad }\end{array}$ \\
\hline $\begin{array}{l}\text { Generation of an information network on innovations } \\
\text { and technology by stages of production processes / } \\
\text { Generación de una red de información sobre } \\
\text { innovaciones y tecnología por etapas de los procesos } \\
\text { productivos }\end{array}$ & $\begin{array}{l}\text { Leveling of production standards in the long term and } \\
\text { among different producers / } \\
\text { Nivelación de los estándares de producción a largo plazo } \\
\text { y entre los diferentes productores }\end{array}$ \\
\hline $\begin{array}{l}\text { Development of a training program on basic aspects / } \\
\text { Elaboración de un programa de capacitación en } \\
\text { aspectos básicos }\end{array}$ & $\begin{array}{l}\text { Leveling of production standards in the medium term / } \\
\text { Nivelación de los estándares de producción (a medio }\end{array}$ \\
\hline
\end{tabular}

Table 10. Actions and results to be followed to increase production.

Cuadro 10. Acciones y resultados a seguir para aumentar la producción.

\begin{tabular}{ll}
\hline Actions / Acciones & Results / Resultados \\
\hline Conclusion of the value chain study / & $\begin{array}{l}\text { General diagnosis of the production process and problem } \\
\text { detection / } \\
\text { Conclusión del estudio de la cadena de valor }\end{array}$ \\
$\begin{array}{l}\text { Diagnóstico general del proceso de producción y detección } \\
\text { de problemas }\end{array}$ \\
$\begin{array}{l}\text { Establishment of the growth potential of crop activities / } \\
\text { Estudies and hydrological plan / }\end{array}$ \\
actividades de los cultivos \\
\hline
\end{tabular}


diminishes their efficiency and competitiveness in the use of irrigation water and complementary activities.

The proper management and use of irrigation water in the modules and in the district itself, through competitiveness and sustainability, show potential for improvement, which should be carried out by correcting a series of actions that are poorly developed internally and externally. Measures must be taken promptly, as the irrigation modules had inadequate irrigation practices, which may ultimately lead to mismanagement of irrigation water use in the district for consecutive agricultural years.

In the irrigation modules, there must be greater linkage among the actors (landowner (user), irrigation module, producer and irrigation district), which will allow successfully carrying out joint projects: increased canal lining, land leveling, rescue of salty soils, profitable agricultural production in order to start redeeming land currently rented, and that really allows benefiting the users who make up the district register and not concentrating production among a few producers.

An urgent task that needs to be carried out by those involved in the study, in order to be more efficient, would be to establish common agricultural practices and stricter oversight of the irrigations carried out by producers, as well as economies of scale through their organizations and service companies. In addition, the volume of water granted to users should be reduced under a prior agreement aimed at benefitting both them and the continuance of agricultural activity in the region.

\section{Acknowledgments}

The authors thank each and every one of the participants, as well as Ing. Humberto Borbón Valencia, Ing. José Ramón Romero Arreola and Ing. Humberto Yocupicio Soto for their collaboration through Irrigation District No. 041 Yaqui River.

End of English version

\section{ESTRATEGIA 3: COMPETITIVIDADY PRODUCCIÓN} Objetivo General: Aumentar la competitividad mediante acciones sobre los aspectos relacionados con todas las etapas de producción. Esta estrategia busca diversificar las actividades y tratar de articular algunas cadenas productivas en los módulos de riego. Esta estrategia está muy relacionada con los resultados que se obtengan del estudio sobre la cadena de valor para el sector que se encuentra en curso.

\section{PROYECTOS:}

\section{Crecimiento de la agricultura.}

Objetivo: Asegurar que la tecnología utilizada en cada una de las etapas relacionadas con la producción de la agricultura pueda alcanzar estándares de eficiencia y calidad (Cuadro 9).

\section{Aumento de la producción.}

Objetivo: Aumentar la importancia de la agricultura en la economía de la región en términos de valor agregado y de empleo (Cuadro 10).

\section{Conclusiones}

Mediante el análisis elaborado y basado en el marco lógico como metodología central, enfocado al distrito y a los módulos de riego, se determinó que se cumple la hipótesis planteada en la investigación; al existir una desvinculación entre actores (usuariosproductores y directivos) que disminuyen su eficiencia y competitividad en el uso de agua de riego y actividades complementarias.

El manejo y uso adecuado del agua de riego en los módulos y en el mismo distrito, mediante la competitividad y sustentabilidad, presentan una mejora potencial, la cual deberá realizarse corrigiendo una serie de acciones que se desarrollan mal interna y externamente. Se deben tomar medidas con prontitud, ya que los módulos de riego contaron con un riego inadecuado, y que a la postre se puede tener una gestión del uso de agua de riego equivocada en el distrito para los consecutivos años agrícolas.

En los módulos de riego, debe existir mayor vinculación entre los actores (dueño de la tierra (usuario), módulo de riego, productor y distrito de 


\section{References / Referencias}

Aldunate, E., \& Córdoba J. (2011). Formulación de programas con la metodología de marco lógico. Instituto Latinoamericano y del Caribe de Planificación Económica y Social (ILPES). Santiago de Chile.

Bedon Martínez, M. A. (2012). Modelo de planificación estratégica basado en el sistema de marco lógico. Caso de aplicación "Fundación Árbol de la Esperanza". Escuela Nacional Politécnica. Facultad de Ciencias Administrativas. Quito, Ecuador. Tesis.

Comisión Nacional del Agua, (2003). Determinación de la disponibilidad de agua subterránea en el acuífero Valle del Yaqui, estado de Sonora. Subdirección General Técnica.

Conza Salas, B. A. (2003). Modelo de identificación, formulación y evaluación de proyectos de desarrollo sostenible aplicado al abastecimiento de agua en zonas marginales: el sistema de marco lógico. Universidad Nacional de Ingeniería. Facultad de Ingeniería Ambiental. Lima, Perú. Tesis.

Goodstein, L., Nolan, T., \& Pfeiffer, J. W. (1998). Planeación Estratégica Aplicada. México, DF: Compañía Editorial Continental, S.A.

Martínez Pellegrini, S. E., Hernández D., Durazo, E., \& Barceló Aguilar J. G. (2010). Política de competitividad de Baja California 2008-2013. Sinergias de segunda generación. El Colegio de la Frontera Norte A.C. Tijuana, B.C.

Montiel, V. M. (2016). Aportaciones de la metodología de marco lógico para la integración de proyectos universitarios. Instituto Tecnológico y de Estudios Superiores de Occidente. Tlaquepaque, Jalisco México. Tesis.

Olmedo Vázquez, V. M., Camacho Poyato, E., Rodríguez Díaz, J. A., Minjares Lugo, J. L., \& Hernández Hernández M. L. (2017). Determinación de indicadores de gestión en los módulos del Distrito de Riego núm. 041, Río Yaqui (Sonora, México). Rev. Fca Uncuyo. 2017. 49(2): 149-168. ISSN impreso 0370-4661. ISSN (en línea) 1853-8665.

Ortegón, E., Pacheco J. F., \& Prieto A. (2005). Metodología del marco lógico para la planificación, el seguimiento y la evaluación de proyectos y programas. Instituto Latinoamericano y del Caribe de Planificación Económica y Social (ILPES). Santiago de Chile. riego), que permita llevar con éxito los proyectos en común con los que se cuentan: incremento en el revestimiento de canales, nivelación de terrenos, rescate de suelos ensalitrados, producción agrícola rentable con la finalidad de iniciar con el redención de tierras en renta, y que permita realmente beneficiar a los usuarios que conforman el padrón del distrito y no concentrar la producción en pocos productores.

Una necesidad urgente que requieren realizar los involucrados en el estudio, para ser más eficientes, sería la de establecer prácticas agrícolas comunes y supervisión más estricta en los riegos realizados por los productores, así como economías de escala a través de sus organizaciones y empresas de servicios. Además de disminuir el volumen de agua otorgada a los usuarios con un acuerdo previo en beneficio de ellos mismos y de la permanencia de la actividad agrícola en la región.

\section{Agradecimientos}

Los autores agradecen a todos y cada uno de los participantes, así como al Ing. Humberto Borbón Valencia, Ing. José Ramón Romero Arreola e Ing. Humberto Yocupicio Soto por su colaboración a través del Distrito de Riego núm. 041, Río Yaqui.

Fin de la versión en español

Porter E. Michael (1990). La ventaja competitiva de las naciones. Javier Vergara Editor S.A.

Rosemberg León J., \& Posner Lawrence D. (1979). The logical framework: a manager's guide to a scientific approach to design and evaluation, Practical Concepts Incorporated. Washington, DC.

Vázquez Morales A. L. (2013). Evaluación mediante el marco lógico del proyecto: conservación de suelos en áreas degradadas en Tlacotepec Plumas, Oaxaca. Universidad Autónoma Agraria Antonio Narro. Coahuila, México. Tesis. 